\title{
A retrospective on: Infrastructure or foreign direct investment?
}

DOI:

10.1108/S1745-8862(2013)0000008015

Link to publication record in Manchester Research Explorer

\section{Citation for published version (APA):}

Yamin, M., \& Sinkovics, R. R. (2014). A retrospective on: Infrastructure or foreign direct investment? In Progress in International Business Research/Prog. Int. Bus. Res. (Vol. 8, pp. 231-247). (Progress In International Business Research). Emerald Publishing Limited. https://doi.org/10.1108/S1745-8862(2013)0000008015

\section{Published in:}

Progress in International Business Research|Prog. Int. Bus. Res.

\section{Citing this paper}

Please note that where the full-text provided on Manchester Research Explorer is the Author Accepted Manuscript or Proof version this may differ from the final Published version. If citing, it is advised that you check and use the publisher's definitive version.

\section{General rights}

Copyright and moral rights for the publications made accessible in the Research Explorer are retained by the authors and/or other copyright owners and it is a condition of accessing publications that users recognise and abide by the legal requirements associated with these rights.

\section{Takedown policy}

If you believe that this document breaches copyright please refer to the University of Manchester's Takedown Procedures [http://man.ac.uk/04Y6Bo] or contact uml.scholarlycommunications@manchester.ac.uk providing relevant details, so we can investigate your claim.

\section{OPEN ACCESS}




\title{
CHAPTER 10
}

\section{A RETROSPECTIVE ON: \\ INFRASTRUCTURE OR FOREIGN DIRECT INVESTMENT?}

\author{
Mo Yamin and Rudolf R. Sinkovics
}

\begin{abstract}
Purpose - This chapter revisits the paper by Yamin and Sinkovics (2009) on the paradoxical relationship between MNE current strategies and economic development. There is evidence that positive developmental impacts of FDI flows are conditional on high levels of human capital and thus on the existence of 'good' infrastructure in recipient countries.

Design/methodology/approach - The chapter makes a conceptual contribution and critically evaluates the key points made in the Yamin and Sinkovics (2009) paper.

Findings - The build-up of infrastructure and enhancement of domestic capabilities are important underpinnings of sustainable development. 'Good' infrastructure, especially basic social infrastructure, is the rock on which otherwise marginalised individuals, groups and country governments can build capabilities.

Research implications - The chapter draws attention to the 'prisoner dilemma' nature of the relationship between MNEs and host
\end{abstract}

\footnotetext{
International Business and Sustainable Development

Progress in International Business Research, Volume 8, 231-247

Copyright (C) 2014 by Mo Yamin \& Rudolf R. Sinkovics

All rights of reproduction in any form reserved

ISSN: 1745-8862/doi:10.1108/S1745-8862(2013)0000008015
} 
governments. Dominant MNE strategies in LDCs create a low payoff for both parties. To proceed towards mutually beneficial outcomes in the $M N E-L D C$ relationship, credible and sustained co-operation between the parties are necessary. Research in the area of mutual value creation has only just emerged in the domain of IB.

Practical implications - Progressing towards 'sustainability' requires that MNE managers are advised to develop a global capability in 'social embeddedness'. LDCs have great potential of becoming strategic markets and important sites for new product and service development. To pursue these opportunities requires credible and sustained commitment to mutual value creation.

Originality/value - This chapter shows that the relationship between $M N E$ strategies and economic development is a contested one. The paper by Yamin and Sinkovics (2009) was one of the first in the domain of IB to suggest that developmental impacts of FDI are contingent on the existence of good infrastructure in recipient countries.

Keywords: Infrastructure; economic development; FDI benefits; multinational strategy; poverty

\section{INTRODUCTION}

Yamin and Sinkovics (2009) explore the paradoxical relationship between MNE strategies and economic development. They suggest that there is evidence that positive developmental impacts of FDI flows are conditional on high levels of human capital and thus on the existence of 'good' infrastructure in recipient countries. Their conclusion is that current MNE strategies may have a negative impact on the development of infrastructure in LDCs, because of resource-poor countries compromising potential basic infrastructure investments by attracting increasingly footloose investment.

The motivation for this chapter was that recent IB discussions of the MNE development had begun to focus on poverty reduction as an important issue (e.g. Dawar \& Chattopadhyay, 2002; London \& Hart, 2004; Ramamurti, 2004). Specifically the work of Prahalad (2004) and London and Hart (2004) who had critiqued the impact of MNEs for its neglect of the bottom of the pyramid as potential markets and contexts for collaborative networks (London, 2009; London \& Hart, 2011), has triggered some considerations of MNE social strategies, legitimacy issues and impacts on 
emerging economies (Karnani, 2007; Reimann et al., 2012; Sinkovics, Sinkovics, \& Yamin, 2014).

The focus on infrastructure in Yamin and Sinkovics (2009) derived directly from the intention to explore how the IB literature could engage with the discourse of developmental impacts on poverty reduction. Our starting point was the observation of a paradox in the IB literature. On the one hand a number of studies investigating, in aggregate terms, the impact of FDI on economic development generate a strong consensus that the positive impact of FDI on economic development was significantly contingent on high levels of human capital development in recipient countries (Yamin \& Sinkovics, 2009, p.149). On the other hand, the radical change in MNE strategies from generally (host country) market-focused, federative structures towards more efficiency-seeking, and de-federative structures (Yamin \& Forsgren, 2006), currently evolved into a literature around the notion of global factories (Buckley \& Ghauri, 2004; Ghauri \& Buckley, 2006). The latter body of work would suggest a low developmental impact.

In this postscript we briefly review our analytical steps in developing the arguments that FDI and infrastructure would be competing for resources to the detriment of LDCs. In retrospect we appreciate that the paper was implicitly criticising both LDC policies and the strategies of MNEs. We conclude by relating our arguments to the specific issue of sustainability and the type of MNE strategies that would be broadly consistent with this aim. We acknowledge the challenging nature of the required strategic shifts that sustainability implies both for MNEs and host country governments. Whilst we recognise that sustainability is inevitably complex and multi-facetted, as the editors have highlighted in the introduction to this book, we argue that a key-prerequisite for sustainability is capability development. Ultimately the debate on the impact of MNEs on LDCs is thus to be seen in light of MNEs' contribution to the capability development in LDCs.

\section{CHANGING MNE STRATEGIES AND STRUCTURES}

Traditionally IB scholarship assumed that the key strategic issue for the MNE was the handling of the tension between the imperative of global integration on the one hand and the need for national responsiveness on the other (Bartlett \& Ghoshal, 1987). The need for national responsiveness, in part, reflected an environment in which national governments 
had significantly more bargaining power in their dealings with MNEs than they generally do nowadays. This dual imperative was reflected in the organization of the MNE. The seminal work of Ghoshal and Bartlett (1990) explained why multinationals would tend to be federative rather than unitary structures, although industry and other contingencies would also be influential in shaping the structure. In the federative structure, national subsidiaries (by which we mean a subsidiary whose focus is very much on the national environment and market of the host country) were an important part of the organization of MNE. Thus, Ghoshal and Bartlett (1990, p. 607) argued that one reason for the limit to the efficacy of headquarters fiat in MNEs was that (some) subsidiaries 'control critical linkages with the host governments'. The basis for the power of national governments was of course control over access to the national economy and in particular to their markets. Multinational expansion frequently took the form of establishing 'miniature replicas', that is subsidiaries which performed several value chain activities in an integrated way and whose main function was to adopt or adapt the products and technologies of the MNE to the market and customer environment of the host countries. Over time however, miniature replicas could become more powerful; focus on the national economy would lead to significant degrees of 'embeddedness' in the national market, meaning that the subsidiary would become rooted in a network of business, technological and institutional actors in the host country (Ghauri, 1992; Phene \& Almeida, 2003). In the words of Phene and Almeida (2003) subsidiaries grow "progressively closer to local host country networks both in terms of sourcing and sharing knowledge' (Phene \& Almeida 2003, p. 363). It has also been found that subsidiary embeddedness in local business and technology networks is an important source of subsidiary strategic capabilities (Andersson, Forsgren, \& Holm, 2002). From the perspective of economic development, this 'old model' of MNE expansion had a positive quality compared to what has replaced it - in potentially encouraging linkages in the domestic economy and the development of industrialization, although in practice the models' implementation was often mired in excessively protectionist policies. Moreover the smaller markets and lower purchasing power of many LDCs constrained the scope for subsidiary development and linkage formation. However the experience of MNE assisted import substitution is not wholly negative (Hirschman, 1968).

Globalization has reduced the need for national responsiveness. MNE strategies are shifting towards greater global (or at least regional) integration (Levy, 2008) and their investment decisions are increasingly motivated 
by efficiency and strategic asset seeking. The MNEs' emerging strategies are underpinned, on the one hand, by their increasingly knowledge-based, intangible and hence mobile core assets and capabilities and, on the other hand, by lower and falling barriers to cross-border operations. This gives MNEs more locational choices, particularly with respect to production and operational activities. Thus MNE strategies revolve around the disintegration of the value chain (Birkinshaw, 2001; Buckley \& Ghauri, 2004) reflecting an increasing ability 'to segment their activities and to seek the optimal location' for narrowly specialised activities (Buckley \& Ghauri, 2004, p. 83). This observation is a central pillow around the notion of the 'global factory' (Buckley, 2009, 2011; Yamin, 2011). In this view of MNE strategy the pattern of FDI flows is influenced by the fact that, increasingly, host countries fit into the strategic calculation of MNEs as sites for key resources or capabilities rather than markets.

All of this has led to a reduction in the importance of nationally focused subsidiaries. Birkinshaw (2001) in fact has observed that the national subsidiary is an 'endangered species'. They have typically experienced a significant reduction in the value chain scope and a shift towards greater operational integration into the MNE and less integration in the host economies where they are located. However despite this general trend, the potential impact of the MNEs' new globalising strategies is likely to be systematically different between developed countries and LDCs. In developed economies, the demise of the national subsidiary has not necessarily meant that they have become totally powerless organizations. They have lost control over market positioning (that is where and who they sell to) as their focus is no longer typically the local market. But they retain the potential to develop resources and capabilities which are valuable in meeting demands of the MNE customers. These are increasingly defined on global or regional rather than individual country basis. There is ample evidence that subsidiaries in developed countries can become major players in the MNE through developing 'global mandates' or becoming 'centres of excellence' (Andersson \& Forsgren, 2000; Birkinshaw, 1996). Thus the narrowing of the value chain scope of subsidiaries does not necessarily imply a withering of subsidiary capabilities in fact they can become capable specialists with a global or regional reach. It all seems to depend on the subsidiary's ability to develop its internal capabilities often in the process of interacting with external counterparts in its local environment (Andersson \& Forsgren, 2000; Birkinshaw \& Ridderstrale, 1999). However the situation seems to be radically different in most LDCs. 


\section{FDI FLOWS TO LDCS: LOW DEVELOPMENT POTENTIAL}

Most developing countries, due to their small population and low per capita income are unlikely to attract much market seeking FDI. Market seeking investment in LDCs is, at any rate, mostly focused on the higher end of the income distribution, incorporating product offerings and marketing policies that mostly bypass the majority of potential (but poor) consumers. However, this may be more a consequence of a weakness of MNE strategies in the LDCs rather than an inherent difficulty in reaching the poor (Dawar \& Chattopadhyay, 2002; London \& Hart, 2004).

In general, LDCs are overwhelmingly attracting 'asset-exploiting' investment, comprising of the transfer of relatively low technology and low value activities to be combined with the main location bound advantages of these countries - mostly cheap and unskilled labour. The dominant trend is LDCs' participation in MNE controlled production networks (Levy, 2008; Nadvi, 2011). LDCs usually enter these networks as sites for the production of highly specified and narrow range of low value-adding activities ('slivers of specialised activity', Buckley \& Ghauri, 2004).

The distinctive contribution of FDI to economic development revolves around its potential to generate positive spillovers. This is the 'external economy' associated with FDI. FDI can generate benefits that are not fully captured by the MNE undertaking the investment. Thus in theory LDC firms gain productivity and knowledge advantages that they don't pay for in full (Zanfei, 2005). The mechanisms through which spillover can occur have been discussed at length in the literature (see, e.g. Bloomström, Kokko, \& Zejan, 2000) and include leaning by and knowledge transfer to domestic firms and enhanced productivity through greater competition induced by the entry of the MNE. The interest in the extent and depth of MNE linkages in the host economy reflect an expectation of the enhanced possibility of knowledge and productivity benefits accruing to the MNEs' local partners at a lower cost than would otherwise be the case. However such an outcome is not automatic and only in rare circumstances does being tied into global value chains actually lead to opportunities for upgrading skills and resources (Giuliani, Pietrobelli, \& Rabellotti, 2005; Pietrobelli \& Rabellotti, 2004). The literature suggests only a positive correlation rather than a definite cause and effect relationship between linkages and spillovers. Generally, the greater the degree of an MNEs' resource commitment to the host economy, through linkages and sourcing of 
intermediate inputs (Rodriguez-Clare, 1996), the greater the degree of positive spillovers are likely to occur in LDCs.

As we indicate in the original paper (Yamin \& Sinkovics, 2009, p. 147), empirical work focused on LDCs conforms to these conclusions. Thus, these findings support the new consensus relating to the low development potential of FDI patterns in LDCs, which replaces the earlier optimism regarding FDI as 'an engine of development' (UNCTAD, 1992).

\section{IMPLICATIONS}

In an endeavour to enrich the assessment of low developmental potential of FDI for economic development, the Yamin and Sinkovics (2009) paper progresses by focusing on how currently dominant strategies of MNEs vis-à-vis LDCs may have negative consequences for the development of infrastructure in these countries and thus aggravate the obstacles to poverty eradication. Fig. 1 encapsulates our arguments, linking low development potential of FDI to reducing investment in basic infrastructure. The two key mechanisms in the process are (a) reduced spillover and linkage effects and thus weaker income multiplier effects of FDI and (b) rising costs and administrative crowding out consequences of attracting footloose FDI. The outcome of this process is reduced government revenue and investment on basic infrastructure.

\section{Reduced Spillover and Linkage Effect}

First, as the discussion of the literature in the previous section indicates, a consequence of current MNE strategies is that the 'quality' of FDI flows to LDCs has declined, meaning that - other things being equal - the prospect that efficiency seeking FDI may promote economic growth is rather discouraging. The reduced spillover and linkage effects associated with the dominant pattern of FDI in LDCs imply a low value added multiplier (Bende-Nabende \& Ford, 1998; Mirza \& Giroud, 2004) in the economy and ceteris paribus a reduced ability to increase public revenue through taxation.

A second effect which we have not yet considered, relates to the rising cost of attracting FDI. This will be discussed in the following sub-section. 


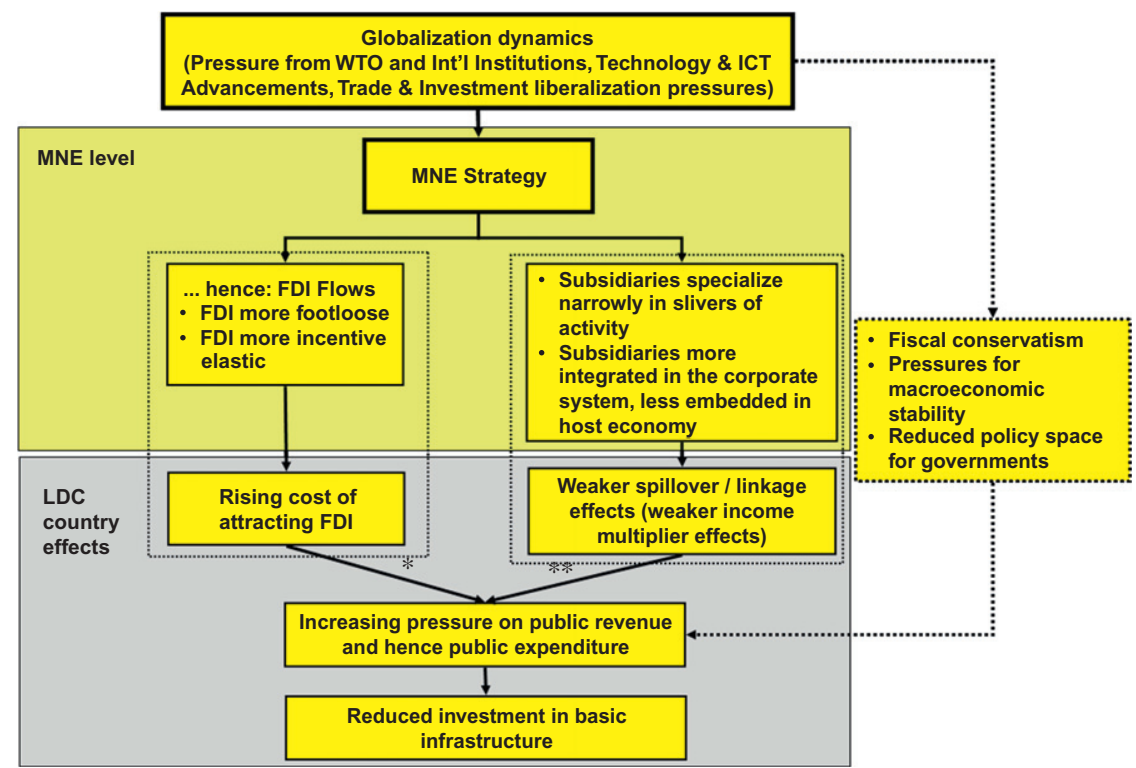

Fig. 1. Linking MNE Strategies to Infrastructure Development in LDCs (Yamin \& Sinkovics, 2009). Note: *increases for countries with weak infrastructure; ${ }^{* *}$ weaker for economies with weak infrastructure.

\section{Attracting FDI: Rising Costs and Administrative 'Crowding Out'}

MNE strategies and the consequent general pattern of FDI flows generate competition between countries to attract footloose FDI which bids up the 'price' that MNEs can extract for locating activities in a particular country or region within the country. The price is further bid up if LDCs have to compete with (the poorer regions of) developed economies whose governments have much greater resources to subsidize incoming FDI (Dunning \& Narula, 2004, p. 30). An important manifestation of this is the increase in the incentive elasticity of FDI flows (Easson, 2001; Mutti \& Grubert, 2004; Taylor, 2000; UNCTAD, 2003). Easson observes that while MNE executives used to downplay the role of incentives, they now readily acknowledge their increasing importance for investment decisions (2001, p. 272). The World Investment Report (UNCTAD, 2003, p. 125) puts recent findings in perspective, noting that locational incentives have become more important as the mobility of firms has increased. Econometric studies that previously found incentives ineffective, now find that they have become more 
significant determinants of FDI flows. The study by Mutti and Grubert (2004) puts emphasis on the variability of (tax) incentive sensitivity across different activities and countries: 'empirical estimates indicated that investment geared towards export markets, rather than the domestic market, is particularly sensitive to host country taxation, that this sensitivity appears to be greater in developing countries than developed countries, and that it is becoming greater over time' (Mutti \& Grubert, 2004, p. 337, emphasis added). MNEs' increasing sensitivity to incentives is itself in part a function of unregulated and uncoordinated competition between countries. As incentives become ever more generous, their weight in the investment calculation of MNE inevitably increases. As Easson has noted, decisions that would not have been influenced by a 'mere' two year tax holiday may well be swayed by a 10 year holiday $(2001$, p. 372 ).

Beyond loss of tax revenue, there are other costs involved in competing for incoming FDI. Many LDCs have created national and regional investment agencies to promote the country or region to foreign investors. A key aim of such agencies is to help improve the investment climate by reducing bureaucratic and administrative costs for investors. Because MNEs can choose amongst different locations and compare transaction and administrative costs across countries, 'attracting them requires not just that transaction costs be lowered, but also, increasingly, that they be benchmarked against those of competing host countries' (UNCTAD, 1999). One measure that many LDCs have adopted to ensure that international investors face minimal costs is to set up one-stop promotion agencies to guide and assist them in getting necessary approvals (UNCTAD, 1999). However, as the UNCTAD report notes, unless the agencies have the authority needed to provide truly one-stop services, they will not be effective. The authority exercised by such an agency is partly a political issue but it does require having competent administrative leadership and operational manpower. The case study of the development of the 'one-stop-shop' investment promotion agency in Egypt suggests that it only became successful after managing to attract a number of highly qualified and experienced administrators to occupy leading positions in the agency (MIGA, 2004). Earlier failure of the agency was partly explained in terms of its staff lacking the 'knowledge, competency, training and authority to grant approvals or licenses, and so were not able to help investors

However attracting MNE through high-powered one stop-shop probably can entail a degree of administrative 'crowding out' in many developing countries, depriving other public policy priorities not only of funding but also of adequate administrative support. This is all the more concerning 
when we take account of the fact that LDCs typically suffer from a generally low level of (public) administrative resources. The absence of skilled and competent state bureaucracy has been held to be an obstacle to economic development and a key difference between the small group of Asian 'tigers' and many other less successful developing countries (World Bank, 1993). In its influential 2001 Report on 'Attacking Poverty' (World Bank, 2001) bemoaned the low quality of state apparatus and its lack of responsiveness to the poor, in particular. The Report puts stress mostly on the institutional aspect of poor public service to the poor; such as the high level of corruption and the arbitrary and non-transparent decision making of state bodies. However it is clear that the development of physical infrastructure may be similarly constrained by inadequate state funding and low organizational capabilities of the state bureaucracy.

Furthermore as most FDI is probably attracted to the already better off regions of the country there will be a greater effort to improve infrastructure in these areas, depriving the poorer regions and the rural areas in particular. Even after years of very rapid growth in the two largest emerging economies (China and India), the rural areas lag significantly in terms of access to basic infrastructure such as heath and sanitation (in India, for example only $23 \%$ of the rural population had access to improved sanitation in 2010 (Asian Development Bank, 2013). Generally the opportunity cost of attracting FDI in terms of constraints on public infrastructure is likely to be even greater for the poorer rural areas in LDCs. Thus we may expect the negative impact of attracting FDI on infra structural development may be greater in rural areas and the poorer regions of LDCs.

Finally we note that the negative impact of attracting FDI is likely to be greater in the large group of non-'catching up' economies. China and India are leading members of the 'catching up' group of emerging economies which have not only attracted large amount of FDI but have also managed to benefit from it. In this group of economies the likelihood that FDI flows may contribute to economic growth is somewhat greater (Zhang, 2001, 2006) and thus the constraint on infrastructure development is eased. In most other LDCs, it has been much easier to attract FDI than to benefit from it, mostly due to absent or low level of complementary human capital and absorptive capacity (Nunnenkamp, 2004). A focus on the implications of MNE strategies for LDC infrastructure is particularly justified for the larger group of non-catching up counties. Thus the negative impact of attracting FDI on infrastructure is greater in countries with low levels of human capital. 


\section{CONCLUSIONS AND IMPLICATIONS FOR MNE STRATEGIES IN LDCS}

The Yamin and Sinkovics (2009) paper endeavoured to explore how FDI flows may have negative effects on public investment on basic infrastructure. It essentially attempted to examine the opportunity costs of FDI in terms of the forgone resources that are not devoted to basic infrastructure. More specifically we argued that shifts in MNE strategy have two related consequences: weaker spillover and linkage effects and greater incentive elasticity of incoming FDI. The first implies a lower income multiplier in the economy and ceteris paribus a reduced ability to increase public revenue through taxation. The effect of the second is to increase competition between actual and potential recipients of incoming FDI and to encourage a more proactive stance with respect to attracting FDI. Thus, a relatively greater portion of public revenues and public administrative and related resources are taken up in attracting incoming FDI.

Both MNE and LDCs are affected by fundamental environmental changes that can rather roughly be described as 'globalization'. The key dynamics of globalization include liberalization relating to trade and investment regulation, and technological advance, particularly in information and communication (ICT) technologies enabling, inter alia, production modularization and geographical flexibility. Yet, in our 2009 paper these forces have not been in the forefront of the analysis. We concentrated on the effects of MNE strategies on infrastructure. However, as indicated in Fig. 1, MNE-related effects constraining the development of infrastructure can be magnified, as LDCs also face pressures emanating from the globalization dynamics which effectively reduce the policy 'space' available to their governments (UNCTAD, 2004).

Thus as Wade (2003, p. 622) and Chang (2008) have argued trade and investment liberalization measures (such as TRIMS and GATS) have resulted in the 'development space' for diversification and upgrading policies in developing countries being shrunk. The rules being written into multilateral and bilateral agreements actively prevent developing countries from pursuing the kinds of industrial and technology policies adopted by the newly developed countries of East Asia, and by the older developed countries when they were developing. Similarly, fiscal 'conservatism' and the demands for macroeconomic stability imply a reduction in the scope for public expenditure (Islam, 2005; Ocampo, 2002). The MNE - related constraints on infrastructural development in a particular country are 
shaped by its macro context in terms of its ability to adapt to globalization pressures. We have not brought this into the forefront of our discussion as we believe that such country capabilities are themselves influenced by the level of infrastructure development.

\section{Implications for MNE Strategy}

Recent IB discussions of the MNE development connections have implicitly and - occasionally explicitly - questioned the efficacy of the dominant MNE strategies in the LDCs (Dawar \& Chattopadhyay, 2002; London \& Hart, 2004; Ramamurti, 2004). The focus on poverty in some recent writings is arguably also a reflection of a critical stance vis-à-vis MNE strategies (Ghauri \& Buckley, 2006; Jain \& Vachani, 2006; Kolk \& van Tulder, 2006). Others have observed the absence of a governance structure to manage the interdependence between LDCs and MNEs (Ghauri \& Cao, 2006; Zanfei, 2005). The key point in discussion is not so much that LDCs have not gained sufficiently from their engagement with MNEs but that current strategies do not serve the MNEs very well either. Thus Dawar and Chattopadhyay (2002) chastise MNEs for being 'trapped by their own devices in gilded cages, serving the affluent few but ignoring the potential of the billions of new consumers'. A similar criticism is developed by London and Hart (2004) who recommend a 'reinvention' of MNE strategies for LDCs and emerging economies and propose a departure from the current low involvement strategies and operational modalities in LDCs. This is an important observation and one that gains significant credence from the investment behaviour of MNEs in developed countries where they have developed collaborative strategies to effectively tap into the created assets of countries and companies (Dunning \& Narula, 2004). London and Hart (2004) cite cases of companies succeeding with "nontraditional' strategies in LDCs. These strategies include developing relationships with non-traditional partners (Doh \& Teegen, 2002), co-inventing custom solutions, and building local capacity. London and Hart (2004) conclude that, these successful strategies suggest the importance of MNEs developing a global capability in 'social embeddedness'. In subsequent contributions (London, Anupindi, \& Sheth, 2010; London \& Hart, 2011), develop this line of thinking, advocating strategies for working with the BOP to generate business models that specifically create social value (London, Anupindi, \& Sheth, 2010). Looking back, we believe our focus on infra-structure ties well with a concern to enhance sustainable 
development. Whilst as the editors have argued sustainability is a complex and multifaceted phenomenon, we believe that enhancing domestic capabilities are an important underpinning of sustainability. 'Good' infrastructure, especially basic social infra-structure can be seen as the rock on which otherwise marginalised individuals, groups and country governments can build capabilities. This is fully in line strategies for mutual value creation advocated by London, Anupindi, and Sheth (2010) and others (e.g. Sinkovics, Sinkovics, \& Yamin, 2014).

We caution however that the adoption of strategies focused on mutual value creation is a challenging phenomenon. In part the challenge lies in the 'prisoner dilemma' nature of the relationship between MNEs and host governments as argued by Zanfei (2005). The dominant MNE strategies in LDCs create a low payoff outcome for both parties. LDCs resources are focused on attracting FDI rather than investing in human capital and infrastructure so as to benefit more fully from incoming FDI. On the other hand current MNE strategies readily ignore the benefits they themselves could derive by helping to develop local capabilities (Oetzel \& Doh, 2009; Zanfei, 2005, p. 12). Many LDCs have great potential of becoming strategic markets and in particular may become important sites for developing new products and services, oriented towards large markets with distinctive cultural and institutional patterns. However, as in the typical prisoner dilemma situation, mutually beneficial outcomes in the MNE-LDC relationship are difficult to obtain as these require credible and sustained cooperation between the parties.

The challenge is arguably even more forbidding for two related reasons. First, even when MNEs are following strategies whereby social embeddedness may be an outcome, such embeddedness does not necessarily traverse areas or communities where poverty reduction is particularly urgent. MNES can be said to 'suffer' a kind of liability of 'outsider ship' with respect to the BOP in particular (Sinkovics, Sinkovics, \& Yamin, 2014). Secondly current strategies have mostly nurtured capabilities for 'flexibility', achieved through 'remote' largely contractual, governing of dispersed and highly 'sliced' activities where local engagement or social embeddedness is not a necessary dimension of good performance (Buckley, 2011; Yamin, 2011). The essence of social embeddedness by contrasts is a commitment to building relationships and engaging with communities over the long term (Tasavori \& Sinkovics, 2011). Given the prevalence of global factory type strategies, MNEs also suffer a capability gap with respect to launching strategies which promote sustainable development. 


\section{ACKNOWLEDGEMENT}

This chapter has built upon the paper previously published in a journal by Yamin, M., \& Sinkovics, R. R. (2009). Infrastructure or foreign direct investment? An examination of the implications of MNE strategy for economic development. Journal of World Business, 44(2), 144-157, Copyright Elsevier 2009. It is reprinted here with full permission from Elsevier.

\section{REFERENCES}

Andersson, U., \& Forsgren, M. (2000). In search of centre of excellence: Network embeddedness and subsidiary roles in multinational corporations. Management International Review, 40(4), 329-350.

Andersson, U., Forsgren, M., \& Holm, U. (2002). The strategic impact of external networks: Subsidiary performance and competence development in the multinational corporation. Strategic Management Journal, 23(11), 979-996.

Asian Development Bank. (2013). Economics and statistics. Manila: Asian Development Bank.

Bartlett, C. A., \& Ghoshal, S. (1987). Managing across borders: New strategic requirements. Sloan Management Review, 28(4), 7-17.

Bende-Nabende, A., \& Ford, J. L. (1998). FDI, policy adjustment and endogenous growth: Multiplier effects from a small dynamic model for Taiwan, 1959-1995. World Development, 26(7), 1315-1330.

Birkinshaw, J. (1996). How multinational subsidiary mandates are gained and lost. Journal of International Business Studies, 27(3), 467-495.

Birkinshaw, J. (2001). Strategy and management in MNE subsidiaries. In A. M. Rugman \& T. L. Brewer (Eds.), The Oxford handbook of international business (pp. 380-401). Oxford: Oxford University Press.

Birkinshaw, J., \& Ridderstrale, J. (1999). Fighting the corporate immune system: A process study of subsidiary initiatives in multinational corporations. International Business Review, $8(2), 149-180$.

Bloomström, M., Kokko, A., \& Zejan, M. (2000). Host country competition, labor skills, and technology transfer by multinationals. Weltwirtschaftliches Archiv, 130(3), 521-533.

Buckley, P. J. (2009). The impact of the global factory on economic development. Journal of World Business, 44(2), 131-143.

Buckley, P. J. (2011). International integration and coordination in the global factory. Management International Review, 51(2), 269-283.

Buckley, P. J., \& Ghauri, P. N. (2004). Globalisation, economic geography and the strategy of multinational enterprises. Journal of International Business Studies, 35(2), 81-98.

Chang, H.-J. (2008). Bad samaritans: The myth of free trade and the secret history of capitalism. New York, NY: Bloomsbury Press.

Dawar, N., \& Chattopadhyay, A. (2002). Rethinking marketing programs for emerging markets. Long Range Planning, 35(5), 457-474. 
Doh, J. P., \& Teegen, H. (2002). Nongovernmental organizations as institutional actors in international business: Theory and implications. International Business Review, 11(6), $665-684$.

Dunning, J. H., \& Narula, R. (2004). Multinationals and industrial competitiveness: A new agenda (New horizons in international business). Cheltenham, UK: Edward Elgar.

Easson, A. (2001). Tax incentives for foreign direct investment part ii: Design considerations. Bulletin for International Fiscal Documentation, 55(8), 365-375.

Ghauri, P. N. (1992). New structures in MNCs based in small countries: A network approach. European Management Journal, 10(3), 357-364.

Ghauri, P. N., \& Buckley, P. J. (2006). Globalization, multinational enterprises and world poverty. In S. C. Jain \& S. Vachani (Eds.), Multinational corporations and global poverty reduction (pp. 204-232). Cheltenham, UK: Edward Elgar.

Ghauri, P. N., \& Cao, X. (2006). Managing the interdependence between multinationals and developing countries. In S. Vachani (Ed.), Transformations in global governance: Implications for multinationals and other stakeholders (pp. 168-186). Cheltenham, UK: Edward Elgar.

Ghoshal, S., \& Bartlett, C. A. (1990). The multinational corporation as an interorganizational network. Academy of Management Review, 15(4), 603-625.

Giuliani, E., Pietrobelli, C., \& Rabellotti, R. (2005). Upgrading in global value chains: Lessons from Latin American clusters. World Development, 33(4), 549-573.

Hirschman, A. O. (1968). The political economy of import-substituting industrialization in latin America. The Quarterly Journal of Economics, 82(1), 1-32.

Islam, I. (2005). Circumventing macroeconomic conservatism: A policy framework for growth, employment and poverty reduction. International Labour Review, 144(1), 55-84.

Jain, S. C., \& Vachani, S. (Eds.). (2006). Multinational corporations and global poverty reduction. Cheltenham, UK: Edward Elgar.

Karnani, A. (2007). The mirage of marketing to the bottom of the pyramid: How the private sector can help alleviate poverty. California Management Review, 49(4), 90-111.

Kolk, A., \& van Tulder, R. (2006). Poverty alleviation as business strategy? Evaluating commitments of frontrunner multinational corporations. World Development, 34(5), 789-801.

Levy, D. L. (2008). Political contestation in global production networks. Academy of Management Review, 33(4), 943-963.

London, T. (2009). Making better investments at the base of the pyramid. Harvard Business Review, 87(5), 106-113.

London, T., Anupindi, R., \& Sheth, S. (2010). Creating mutual value: Lessons learned from ventures serving base of the pyramid producers. Journal of Business Research, 63(6), $582-594$.

London, T., \& Hart, S. L. (2004). Reinventing strategies for emerging markets: Beyond the transnational model. Journal of International Business Studies, 35(5), 350-370.

London, T., \& Hart, S. L. (2011). Next generation business strategies for the base of the pyramid: New approaches for building mutual value. Upper Saddle River, NJ: FT Press.

MIGA. (2004). Multilateral investment guarantee agency. Washington, DC: World Bank Group.

Mirza, H., \& Giroud, A. (2004). Regionalization, foreign direct investment and poverty reduction. Journal of the Asia Pacific Economy, 9(2), 223-248.

Mutti, J., \& Grubert, H. (2004). Empirical asymmetries in foreign direct investment and taxation. Journal of International Economics, 62(2), 337-358. 
Nadvi, K. (2011). Labour standards and technological upgrading: Competitive challenges in the global football industry. International Journal of Technological Learning, Innovation and Development, 4(1/2/3), 235-257.

Nunnenkamp, P. (2004). To what extent can foreign direct investment help achieve international development goals?. World Economy, 27(5), 657-677.

Ocampo, J. A. (2002). Rethinking the development agenda. Cambridge Journal of Economics, 26(3), 393-407.

Oetzel, J., \& Doh, J. P. (2009). MNEs and development: A review and reconceptualization. Journal of World Business, 44(2), 108-120.

Phene, A., \& Almeida, P. (2003). How do firms evolve? The patterns of technological evolution of semiconductor subsidiaries. International Business Review, 12(3), 349-367.

Pietrobelli, C., \& Rabellotti, R. (2004). Upgrading in clusters and value chains in Latin America: The role of policies. Washington, DC: Inter-American Development Bank.

Prahalad, C. K. (2004). The fortune at the bottom of the pyramid: Eradicating poverty through profits. Upper Saddle River, NJ: Wharton School Publishing.

Ramamurti, R. (2004). Developing countries and MNEs: Extending and enriching the research agenda. Journal of International Business Studies, 35(4), 277-283.

Reimann, F., Ehrgott, M., Kaufmann, L., \& Carter, C. R. (2012). Local stakeholders and local legitimacy: MNEs' social strategies in emerging economies. Journal of International Management, 18(1), 1-17.

Rodriguez-Clare, A. (1996). Multinationals, linkages, and economic development. The American Economic Review, 86(4), 852-873.

Sinkovics, N., Sinkovics, R. R., \& Yamin, Mo. (2014). The role of social value creation in business model formulation at the bottom of the pyramid - Implications for MNEs? International Business Review.

Tasavori, M., \& Sinkovics, R. R. (2011). Socially entrepreneurial behaviour of multinational companies: Are MNCs 'social entrepreneurs'? In E. Hutson, R. R. Sinkovics, \& J. Berrill (Eds.), Firm-level internationalisation, regionalism and globalization (pp. 397-411). Houndmills, UK: Palgrave Macmillan.

Taylor, C. T. (2000). The impact of host country government policy on US multinational investment decisions. The World Economy, 23(5), 635-647.

UNCTAD. (1992). World investment report 1992 - Transnational corporations as engines of growth. New York, NY: United Nations.

UNCTAD. (1999). World investment report 1999 - Foreign direct investment and the challenge of development. New York, NY: United Nations.

UNCTAD. (2003). World investment report 2003 - FDI policies for development: National and international perspectives. New York, NY: United Nations.

UNCTAD. (2004). World investment report 2004 - The shift towards services. New York, NY: United Nations.

Wade, R. H. (2003). What strategies are viable for developing countries today? The world trade organization and the shrinking of 'development space'. Review of International Political Economy, 10(4), 621-644.

World Bank. (1993). World development report 1993: Investing in health. New York, NY: World Bank.

World Bank. (2001). World development report 2000: Attacking poverty. New York, NY: Oxford University Press. 
Yamin, M. (2011). A commentary on peter buckley's writings on the global factory. Management International Review, 51(2), 285-293.

Yamin, M., \& Forsgren, M. (2006). Hymer's analysis of the multinational organization: Power retention and the demise of the federative MNE. International Business Review, 15(2), $166-179$.

Yamin, M., \& Sinkovics, R. R. (2009). Infrastructure or foreign direct investment?: An examination of the implications of MNE strategy for economic development. Journal of World Business, 44(2), 144-157.

Zanfei, A. (2005). Globalization at bay? Multinational growth and technology spillover. Critical Perspectives on International Business, 1(1), 5-17.

Zhang, H. K. (2006). Does international investment help poverty reduction in China? Chinese Economy, 39(3), 79-90.

Zhang, K. H. (2001). Does foreign direct investment promote economic growth? Evidence from east Asia and latin America. Contemporary Economic Policy, 19(2), 175-185. 